\title{
The Issues and Implications About the Volatility of the Stock and the Bond Prices and Their Returns and the Volatility of Interest Rates and Inflation - Which Are Being Researched in Finance and Macro-Monetary Economics Literature: A Survey
}

\author{
Muthucattu Thomas Paul \\ Correspondence: Professor and Head, Applied Economics Section, Department of Business Studies, Papua New Guinea \\ University of Technology, Lae-411, Morobe Province, Papua New Guinea.
}

Received: October 20, 2017

doi:10.11114/aef.v5i2.3023
Accepted: February 6, $2018 \quad$ Available online: February 11, 2018

URL: https://doi.org/10.11114/aef.v5i2.3023

\begin{abstract}
Volatility of returns of the financial assets, and the volatility of the inflation and aggregate demand, are important issues in the Financial markets, and the macro- monetary economics. In this article, the volatility in the stock and bond markets are surveyed and discussed in detail. Our view is that the higher volatility in the long-term rates than in the short-term rates, may be due to the higher leverage effect in the long-term markets and rates than in the short -term rates. In the previous century, last fifty years, the average stock returns were much higher and the expected return or the cost of capital was lower. The conditional volatility models and the volatility spill over between the spot and futures markets and their implications are deeply explored in this article along with the price discovery between spot and futures markets and the conditions for the efficiency in these markets. In our section dealing with Macro- monetary economics, the effect of the variability of inflation on the demand for money function, on the nominal rates of interest, and on the slope of the aggregate supply curve, are brought into sharp focus and is being discussed through the relevant literature survey.

Keywords: variance-bound test, persistence in volatility, financial markets, Spot and futures market, returns of the assets, price discovery, efficient markets, the variability inflation, the demand for money function, Fisher effect, inflationary expectation, nominal and real interest rates, rational expectation, cointegration, error-correction models, asymmetric information, Granger-casualty, dividend/price ratio
\end{abstract}

JEL Classification: C22; G15; E44; E2.

\section{Introduction}

Volatility of returns of the financial assets, and the volatility of inflation and aggregate demand are important concepts, respectively used in Financial Economics, and Macro-Monetary Economics. This article attempts a critical survey of the issues in the use of the volatility in Finance and Macro- Monetary Economics. Instability in markets, that is, unjustified or excessive volatility of financial asset prices, can be a matter of concern to the policy makers. This is not only because asset-price volatility can be associated with problems for the institutions that are active in the markets concerned, but also because changes in prices of financial assets have direct effect on private sector spending. (Crockett 1997). These effects occur because of changes in the private sector's stock of wealth, and because of the effect of changes in the rate of return on incentives to save and invest. Fama \& French (2002) remind us that, according to finance theory, the objective of investment is consumption, either present or future, and hence the investor is interested in the real returns adjusted for inflation. Also, the volatility in inflation rates affect the nominal and real interest rates, which are important for discounting cash flows from the assets and for finding the expected returns of the assets, and the cost of capital. In the market for fixed income securities -bonds-, the market interest rate is highly relevant to discount and find the present values of all future cash flows of the fixed income securities. Market interest rates are determined by the inflation and expectation of inflation (Fisher 1930). Changes in the macroeconomic climate can cause investors to reevaluate their expectations for inflation and real interest rates, thus sometimes causing the abrupt changes in the prices of fixed income securities. Because the volume of investment financed by bonds and long-term borrowing is typically much larger than by financing through equities, a movement in bond yields will have a pervasive influence on the 
overall investment climate. The aforementioned are the broad factors which in our view, produce a linkage between the volatility in asset prices, and the volatility in inflation rates, and hence our reasons to link the volatility in asset prices and the volatility in inflation rates: this is the rationale for our sections 4., discussing the volatility in the prices/ inflation rates in the Macro-Monetary Economics, along with other sections discussing the financial market volatility. However, it focuses more on the issues in the financial markets, specifically on the spot and futures markets. In this context, it explores the recent issues in the conditional and unconditional volatility. Nevertheless, it also surveys briefly the exciting theoretical issues in the Financial Economics of the stock and the bond market volatilities, and in the macro- monetary economics where the volatility of inflation and aggregate demand are relevant. Therefore, this article is a critical survey of the issues related to the volatility in financial markets - the stock, and bond markets, and the market for interest rates and lending and borrowing of money. The objective of the paper is not to produce the empirical evidence and not to do new empirical research with data.

In some respects, the factors that cause the volatility in asset prices are similar to those that create instability in financial institutions. Estimates of the net-worth of financial institutions is volatile. Similarly, the pricing of financial asset is subject to imperfect information. Neither the stream of future income nor the factors which affect the rate at which it will be discounted by the market are known to individual asset holders. These uncertainties shows up in the volatility of prices of the marketable securities, and in the quantities of the non- marketable assets such as deposits and loans. The financial crises of the 1980s, 1990s, and 2000s bear testimony to this volatility of the financial markets. The specific determinants of asset-price volatility, and the channels by which they can affect the real economy, depend on the characteristics of the market concerned (Krugman 1991)

In section 2 we discuss the concepts and empirical issues related to the return and volatility in financial markets, including the applied econometric and time series issues of the conditional and unconditional volatility. Section 3 deals with the causes for the volatility in financial prices, especially that of the stocks from the perspectives of both Economics and Finance. Recall our discussion in this introduction about the rationale for discussing the volatility of the inflation rates along with the volatility of the financial prices and markets, and hence in the section 4, we discuss the macro- monetary economics of the volatility of inflation and its effect on interest rates and the demand for money. Section 4.1 covers the bond market volatility. In section 4.2 Issues and critical survey of the literature on Spot and futures market returns volatility and the linkages, are discussed. In section 5., issues for research are discussed. Section 6 gives the conclusions

\section{Returns and Volatility in Financial Markets}

Volatility is measure of price volatility over some period of time. It describes the standard deviation of returns in a particular context that depends on the definition used. The standard deviation of the continuously compounded return during any T-year period is then the volatility of the returns stand in financial economics as a proxy for the risk in financial markets. Returns equal changes in the logarithms of the prices, with appropriate adjustments when dividends are distributed.. This combines single period return to multiperiod returns. Though these compounded returns are similar to per cent returns, both are not the same The limited liability principle in finance cannot allow a loss more than losing total investments or $-100 \%$. If the expected return is $-30 \%$ and the standard deviation is $30 \%$, the maximum loss can exceed $-100 \%$ for $1 \%$ probability, which the finance theory does not allow. Secondly with log difference returns, the continuously compounded multiperiod return is simply the sum of continuously compounded single period returns Furthermore, if the continuously compounded single period returns are normally distributed, the multiperiod returns will also be normally distributed. Deriving the properties of additive time series is easier than deriving the properties of the mutilative time series. When the Options and such complex financial products are used continuous compounding is used to such an extent that it has become standard practice in finance literature because of the ease in applying calculus. for pricing derivative financial products.

\subsection{Historical Volatility}

Realized or historical volatility is the standard deviation of a set of previous returns. For $\mathrm{n}$ trading periods and returns $\mathrm{r}$ $-1, \ldots . r_{-n}$ whose average is $r^{-}$the historical standard deviation

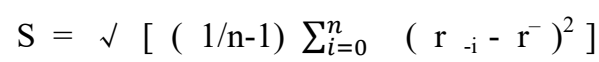

This provides a simple estimate of the standard deviation of the return for trading period $t$.

Volatility is measure of price volatility over some period of time. It describes the standard deviation of returns in a particular context that depends on the definition used. The standard deviation of the continuously compounded return during any $\mathrm{T}$-year period is then

$\sigma \sqrt{ }$ Twhatever the prior history of the assets price. This definition is applicable whenever prices are assumed to follow geometric Brownian motion (GBM), But in actual practice GBM may not hold as future price variability may depend 
on recent history of prices. However, it has been found very useful in in defining a parameter that predicts the determination of option prices.

Conditional Volatility is the standard deviation of a future return that is conditional on known information such as history of previous returns. Stochastic volatility process are motivated by noting that volatility is not constant and hence it is rewarding to specify a process through which the volatility is evolving over time.

ARCH (1)

The simplest example of an ARCH process is ARCH (1) specification presented by (Engle(1982). The distribution of the return for return for period $t$, conditional on all previous return is normal with a constant mean $\mu$ and time varying conditional variance $\mathrm{h}_{\mathrm{t}}$ denoted by

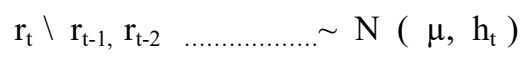

and

$$
\mathrm{h}_{\mathrm{t}}=\mathrm{u}+\alpha\left(\mathrm{r}_{\mathrm{t}-1}-\beta\right)^{2}
$$

The volatility parameters are $\mathrm{m}>0$ and $\alpha \geqslant 0$. The volatility in period $t$ then depends solely on the previous return. Either a large positive or large negative return in the previous period implies a higher than average volatility in the current period when ais positive. Conversely a normal return near to $\mu$ in the previous period implies a lower than average volatility in next period.

$$
\begin{gathered}
e_{t}=r_{t}-\mu \\
e_{t}^{2}=w+\alpha e_{t-1}^{2}+V_{t}
\end{gathered}
$$

And hence squared residuals follow AR(1) process. As long as the mean $\mu$ is constant the residuals squares are auto correlated. This in turn implies that returns may be correlated. Therefore, financial economists point out that ARCH (1) model may violate the efficient market hypothesis. The autocorrelations are defined when $\mathrm{e}_{\mathrm{t}}{ }^{2}$ has a finite variance, which requires $3 \alpha^{2}<1$. A natural alternative is ARMA process and that explains the interest in GARCH models.

\subsection{Symmetric GARCH Model}

This section examines and discusses different volatility models in the literature especially that we have employed in this study.

In a GARCH framework the variance is conditional and time-varying. The return equation is

$$
R_{t}=\omega+\sum_{j=1}^{m} \lambda_{j} R_{t-j}+\varepsilon_{t}
$$

Where $\varepsilon_{t}$ is a Gaussian innovation with zero mean and a time-varying conditional variance $h_{t}$. Lagged values of the return variable are incorporated in equation (1) to deal with the problem of autocorrelation and ' $m$ ' is the lag order. The autoregressive lag order ' $\mathrm{m}$ ' is chosen on the basis of Schwarz information criteria (SIC).

Engel, Lilien, \& Robins (1987) suggested the implementation of ARCH-in-mean or ARCH-M specific to let the return of a security to be partly determined by its risk. A GARCH-M specification would incorporate the conditional volatility in the mean equation of the GARCH process so that the conditional volatility can generate a risk premium, which is a part of expected returns. The mean equation (1) for stock returns modified to include conditional variance is shown in equation $(7)^{1}$.

$$
R_{t}=\omega+\sum_{j=1}^{m} \lambda_{j} R_{t-j}+\varphi h_{t}+\varepsilon_{t}
$$

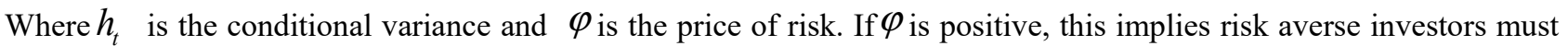
be compensated for taking on higher risk. However the positive risk-return relationship is not always corroborated by empirical evidence ${ }^{2}$.The conditional variance $h_{t}$ in the GARCH $(\mathrm{p}, \mathrm{q})$ model depends on the period's lagged square error term and on its own previous lag. Thus

$$
h_{t}=\mu_{o}+\sum_{j=1}^{p} \beta_{j} h_{t-j}+\sum_{i=1}^{q} \alpha_{i} \varepsilon_{t-i}^{2}
$$


Equation (7) and (8) are estimated using Quasi Maximum Likelihood Estimation (QMLE). As the standardized residuals $\left(\varepsilon_{t} / \sqrt{h_{t}}\right)$ are not normally distributed, the usual standard error estimates due to Bollerslev, Chou, \& Kroner (1992) have been used. The procedure of maximum likelihood with Bollerslev-Woolridge standard errors is known as Quasi-Maximum Likelihood Estimation (QMLE).

The GARCH (p, q) specification requires in equation (8) :

$$
\begin{aligned}
& \alpha+\beta<1 \\
& \beta_{j} \geq 0 \\
& \alpha_{i} \geq 0
\end{aligned}
$$

Equation (9) ensures non-explosiveness while (10) and (11) ensures non-negativity of conditional variance.

The GARCH $(1,1)$ parameters can be interpreted to give estimates of volatility persistence and mean reversion. Higher values for ARCH coefficient $\alpha$ would generate more "spiky" diagram of returns, i.e. conditional volatility would show large reaction and low persistence. The volatility of the Return in period ' $t$ ' depends on previous Return. Either a large positive or large negative Return in period t-1 implies higher than Higher than average volatility in the next period when ais positive; conversely Returns near the mean levels Bimply lower than average future volatility. values of the GARCH coefficient $\beta$ in the volatility equation measure the persistence of volatility. SIC is used to determine the appropriate order of $\mathrm{p}$ and $\mathrm{q}$. The optimal model corresponds to the $(\mathrm{p}, \mathrm{q})$ combination corresponding to the lowest value of SIC.

Ling \& McAleer (2002a) established the necessary and sufficient condition for the existence of the second moment $\varepsilon_{t}$ for GARCH $(1,1)$ model: $\alpha+\beta<1$, the unconditional variance $\mu_{o} /(1-\alpha-\beta)$ is finite and unconditional kurtosis is greater than 3(i.e. leptokurtic distribution) and can be infinite. The correlation between Returns is zero. The process is stationary when $\alpha+\beta<1$.

\subsection{Asymmetric GARCH Models}

Symmetric GARCH models cannot capture the leverage effect inherent in most stock market data. Positive and negative stock return innovations have different impact on the volatility, as found in the literature by many researchers (Campbell \& Hentschel 1992, Engle \& Ng 1993). Two basic asymmetric GARCH models, namely TARCH and EGARCH, have been designed to capture the leverage effect (Bhattacharya and Roy 2009).

\subsection{Exponential GARCH Model}

EGARCH model was proposed by Nelson in 1991. An EGARCH $(1,1)$ process is defined as

$$
\log \left(h_{t}\right)=\mu_{o}+\beta \log \left(h_{t-1}\right)+\alpha\left|\frac{\varepsilon_{t-1}}{\sqrt{h_{t-1}}}\right|+\gamma \frac{\varepsilon_{t-1}}{\sqrt{h_{t-1}}}
$$

Nelson (1991) originally assumed that $\varepsilon_{t}$ follows a General Error Distribution (GED). However, the model can also be estimated using the assumption that $\varepsilon_{t}$ follows a normal or student-t distribution. When errors are normally distributed the specification for conditional variance differs by an additional term from the original specification ${ }^{3}$.

$$
\log \left(h_{t}\right)=\mu_{o}+\beta \log \left(h_{t-1}\right)+\alpha\left|\frac{\varepsilon_{t-1}}{\sqrt{h_{t-1}}}-\sqrt{\frac{2}{\pi}}\right|+\gamma \frac{\varepsilon_{t-1}}{\sqrt{h_{t-1}}}
$$

The conditional variance for an $\operatorname{EGARCH}(\mathrm{p}, \mathrm{q})$ process is specified as

$$
\log \left(h_{t}\right)=\mu_{o}+\sum_{i=1}^{p} \beta_{i} \log \left(h_{t-i}\right)+\sum_{j=1}^{q}\left(\alpha_{j}\left|\frac{\varepsilon_{t-j}}{\sqrt{h_{t-j}}}-\sqrt{\frac{2}{\pi}}\right|+\gamma_{j} \frac{\varepsilon_{t-j}}{\sqrt{h_{t-j}}}\right)
$$

The left-hand side of the equation (14) is the logarithm of conditional variance. This ensures that even if the parameters are negative, $\sigma_{t}^{2}$ will be positive. Thus there is no need to impose any non-negative constraints on the model parameters $\alpha, \beta$ and $\gamma$. The only restriction in the EGARCH model is the condition that the sum of the ARCH and GARCH terms must not exceed unity in order to guarantee that the process is stationary. The leverage effect is captured by $\gamma$. The impact is symmetric if $\gamma \neq 0$. If $\gamma<0$, good news generates less volatility than bad news. In case of good news, $\varepsilon_{t-1}>0$ and total contribution of innovation is $\alpha(1+\gamma) \varepsilon_{t-j}$.In case of bad news, the contribution to volatility $\alpha(1-\gamma) \varepsilon_{t-j}$. 


\subsection{TARCH Model}

The TARCH model (Glosten, Jagannathan, \& Runkle 1993), (Zakoian 1994) extends the original GARCH model by including a dummy variable specification in the conditional variance equation. The conditional variance equation for $\operatorname{TARCH}(1,1)$ model is

$$
h_{t}=\mu_{o}+\beta \mathrm{h}_{\mathrm{t}-1}+\alpha \varepsilon_{t-1}^{2}+\gamma \varepsilon_{t-1}^{2} d_{t-1}
$$

Where $\alpha, \beta$ and $\gamma$ are constants and $\mathrm{d}$ is the indicator of dummy variable.

$$
d_{t-1}=1 \text {, if } \varepsilon_{t-1}<0 \text { and } d_{t-1}=0 \text {, if } \varepsilon_{t-1}>0
$$

The conditional variance equation for $\operatorname{TARCH}(p, q)$ model is

$$
h_{t}=\mu_{o}+\sum_{j=1}^{p} \beta_{j} \mathrm{~h}_{\mathrm{t}-\mathrm{j}}+\sum_{i=1}^{q} \alpha_{i} \varepsilon_{t-i}^{2}+\sum_{i=1}^{q} \gamma_{i} \varepsilon_{t-i}^{2} d_{t-i}
$$

The model is formulated on the assumption that unexpected changes in market returns will have a differential impact on the conditional variance of returns. Good news $\left(\varepsilon_{t-1}>0\right)$ contributes to an increase in variance through the coefficient $\alpha$. In case of bad news $\left(\varepsilon_{t-1}<0\right)$ there is a decrease in variance through the coefficients $\alpha+\gamma$. An intuitive measure of the degree of symmetry is $(\alpha+\gamma) / \alpha$. When $\gamma \neq 0$, implies asymmetric effect is present. However, if $\gamma=0$, the model becomes a GARCH model. Positive value of $\gamma$ implies bad news increases volatility more than what good news does. For TARCH model the following parameter restrictions: $\mu_{o} \geq 0, \alpha \geq 0, \beta \geq 0$ and $\alpha+\gamma \geq 0$ must hold to ensure positive conditional variance. The TARCH $(1,1)$ model is symmetric as long as $\gamma \neq 0$ (.Ling \& McAleer 2002b) established the regularity condition for the existence of the second moment of TARCH $(1,1)$ model, which is $((\alpha+\beta+\gamma) / 2)<1$.

\section{Explanations of the Changes in Volatility and Its Impact in Economics and Finance}

The volatility of the asset prices is not the same at all times. The conditional volatility models precisely point out that the volatility is not constant over time. The traders also believe that volatility is not constant, because implied volatilities vary considerably over time used in option prices quotations in the markets.

Stock market volatility increases during crises and then decreases during normal times. The economic crises such as the Great Depression of the 1930s and the 2008 US financial market crisis, were accompanied by the higher volatility in the stock markets. Volatility was much higher after September 11, 2001 in US markets.

Macroeconomic news releases on variables such as inflation, employment, and GNP have an impact upon the volatility of stock, foreign exchange and interest rate markets Inflation, money growth, and industrial production account for a small per cent of volatility of stocks over long periods of time (Schwert 1989)

A negative shock may result in a greater price movement than the positive shocks will, because markets tend to require compensation against the risks. Also, stock market volatility is dependent on the level of the market. When equity prices fall, the value of the debt relative to equity increases, and this leads to an increase in financial leverage. At the same the volatility increases on average (Black 1976), (Christie 1982).

Stock market fluctuations can also be engendered by herd behavior, that is similar in nature and justification to the behavior of the bank depositors, who try to withdraw the deposits, though they know very well that in aggregate if everyone withdraws bank deposits, it will be against the interest of everyone, if the bank collapses. An increasing proportion of equity holdings is concentrated in the hands of funds managers (Davis,1996). Their optimum strategy is not to depart from the market judgement. There will thus a tendency to follow the market trends, even at the cost of amplifying the market fluctuations. (Scharfstein \& Stein,1990)

Stock prices might be heavily influenced by information about a major disaster (such as wars, natural disasters.) If the disaster is big enough, changing probability of it might be enough to cause major fluctuations in stock prices, even though the disaster did not occur in the last century. High probabilities of disaster may be inconsistent with the fact that the disaster has never occurred. Shiller (1985), Mankiw, Romer, \& Shapiro (1989), Schwerte (1987) have pointed out that during war times United States have not been periods of relatively high volatility in stock prices, even though these times correspond to a high volatility about a number of other macroeconomic variables. Still such stories about potential variability in dividend distribution may affect the stock market volatility to some extent.

Another explanation for market fluctuations has been found in certain technical features of trading and market structures. Any feature that facilitates buying in a rising market and selling in a falling market has the potential to 
exacerbate price volatility. Dealing on credit or margin is the most common such feature. And when price begin to fall, investors are forced to sell due to margin calls. Leveraging obviously lead to high risk and volatility in stock markets. A related feature is the introduction of financial innovations such as derivative markets including the forward markets in stocks, and if they accentuate the volatility in the spot markets of stocks. This aspect is dealt in detail in our section 4.2.

Bubbles are hardly unusual. They have a centuries-long history of hitting markets from tulips to stocks, bonds, housing and many other assets. What is really unusual about the current global bubble is that it is hitting everything at once -from stocks to art, fine wine and bitcoin. Driven by record low interest rates and a surge of global liquidity, (Ruchir S. 2018) composite index of stock, bond and housing valuations is at a record high, higher than 2000 or 2007.

The result is that while the total worldwide value of stocks and bonds was about equal to the size of the global economy in 1980, it is now 3.5 times higher. Traditionally, economists have seen markets as a reflection of underlying economic trends, but now they are large enough to dictate those trends. The tail could wag the dog: a disruption in markets could come back to bite the real economy. As the market goes up, people feel richer and save less, which means they are not as well-prepared for a market-induced economic shock if it comes. (Ruchir S.2018)

In fact, central bank policies have convinced many investors that nothing can go wrong, all but ending the volatility and frequent corrections that normally roil markets. In the US, the average market correction in any given year is just over 10 per cent; in 2017, the biggest correction was a mere 3 per cent. In India, the average correction has been 18 per cent in 2017 , the biggest was 4 per cent. The problem with this record calm is that it goes against the volatile nature of capitalism and markets (Ruchir S. 2018), and is thus not likely to last. Interest rates are beginning to rise, which could undermine investors' current impulse to buy immediately on every dip, and thus bring back volatility. However, Ruchir.S.2018)'s definition of volatility is average percent of market correction, which may be biased towards downside movement and is not standard definition of volatility which considers both up and down movements from the average. Therefore, upwards movements in the current boom are ignored in his definition of volatility.

Some variations in volatility are explained through asset pricing models, for example, models that assume that investors have asymmetric information (Brock, \& LeBaron, 1996); (Timmermann, 2001), who propose that the rational agents must infer the degree of persistence of fundamental shocks.

Volatility is positively correlated with trading volume (Karpoff 1987); (Gallant Rossi \& Tachen 1992). But which is cause and which is effect is not certain, and both may be produced by other factors).

An important explanation of the stock price volatility is the dividend setting stochastic process. One line of thinking is that any change in dividends from year to year tend to cause a major change in all future expected dividends. Here there is a notion that dividends do not revert to any previous trends or the dividends stochastic process has a unit root. In the $\log$ random walk process for dividends, if dividends increase by $10 \%$ from one year to the next, then all subsequent optimally predicted future dividends are also increased by $10 \%$.. Therefore, these models build in a lot of price volatility. However, it is pointed out that dividends seem to show only short rum fluctuations and real dividends appear to show a tendency to revert to trend. In the long- run, the true mean of the dividend - price ratio is constant, and the conditional mean of the dividends - price ratio will show a lot of variability. Marsh \& Merton (1986) claimed that there was a reason to expect a dividend process like the random walk. They claimed that the work of Lintner, J. (1956), who interviewed the managers on their dividend setting behavior, implied that managers set dividends in proportion to "permanent earnings", which is proportional to firm's "intrinsic value". Since under efficient markets, price equals intrinsic value, managers in effect set dividends in response to price. Since intrinsic value is the present value of all future dividends, there is an implied permanence to shocks to dividends. Thus the managers dividends setting rule leads to the appearance of a random walk in dividend stochastic process. In the recent years, Fama \& French (2002)point out that stock repurchase as giving dividends also leads to the non-stationarity in dividend/ stock price ratios.

The efficient market model is tested by Shiller (1981a) through

$$
p_{t}=\mathrm{E}_{\mathrm{t}}\left(\mathrm{p}_{\mathrm{t}}^{*}\right)
$$

where $p_{t}$ is real stock price index (detrended by dividing by a factor proportional to long run exponential growth path), and $\mathrm{p}_{\mathrm{t}}{ }^{*}$ is the present discounted value of the actual subsequent real dividends ( also as a proportion of the long-run growth path).E is the Expectation operator. $\boldsymbol{p}_{t}$ is the mathematical expectation of conditional on all available information available at time tof $\mathrm{E}_{\mathrm{t}}\left(\mathrm{p}_{\mathrm{t}}{ }^{*}\right)$. One can define the forecast error

$$
u_{t}=p_{t}^{*}-p_{t}
$$

Recalling that a fundamental principle of the optimal forecast is that the forecast error $u_{t}$ must be uncorrelated with the forecast ; that is, the covariance between $p_{t}$ and $\mathrm{u}_{\mathrm{t}}$ must be zero. If the forecast error is correlated with forecast itself, then the forecast could be improved. 
If one uses the principle from elementary statistics that the variance of the sum of two uncorrelated random variables is the sum of their variances, then we get,

$$
\operatorname{var}\left(p^{*}\right)=\operatorname{var}(u)+\operatorname{var}(p) .
$$

Since variances cannot be negative, this mean that

$$
\operatorname{var}(p) \leqslant \operatorname{var}\left(p^{*}\right)
$$

This inequality (LeRoy \& Porter (1981)) is violated dramatically in empirical studies.

Shiller (1981a) has further developed this variance inequality in terms of innovations in real dividends model, which implied that innovation in price is related to innovation in dividends. Further the variance of innovation of price is maximized when information about dividends is revealed in a smooth fashion so that the standard deviation of the new information at time $t$ about a future dividend, $d_{t+k,}$ is proportional to the weight in the present value formula. It has been repeatedly found that stock price change distributions show high kurtosis or "fat tails". This means that in a long-time series of the changes in stock price $(\Delta \mathrm{p})$ one sees long stretches of time when their absolute values are very small and them occasionally a extremely large absolute value change. This phenomenon is commonly attributed to a tendency for new information to come in big lumps infrequently. There seems to be a common presumption that this information lumping might cause stock price changes to have high or infinite variances, which would seem to contradict the conclusion that variance of price is limited and is maximized if forecasts might have a simple autoregressive structure. But Shiller(1981a) pointed out that high sample kurtosis does not necessarily indicate infinite variances and instead suggests that the existence of moments for the price series is implied by the existence of moments for the dividends series. Though Shiller(1981a) was hinting the reason for the higher volatility in the stock price was the time varying real discount rates, Shiller was skeptical about testing that hypothesis. Considering the empirical fact that the stock price volatility of the last century appear to be too high, one way to explain it is through changes in expected real interest rates. But Sheller's calculations (1981a) showed that the order of magnitude needed of the changes in real interest rate was much high to explain such higher volatility in stock prices, much higher than the actual changes in nominal interest rates. But another way of saving the general notion of efficient markets and to explain the higher stock volatility, according to Shiller(1981a) is to say that our measure of the uncertainty regarding future dividends-the sample standard deviation of the movements real dividends around their long-run exponential growth path -understates the true uncertainty about the future dividends. In those days the conditional standard deviations- volatility- was not much applied in those research areas and needs much updating with ARCH and GARCH modeling. But the movements in real dividends the market feared- expected-must have been many times larger than those observed in the Great Depression of the 1930s.Also, the expected returns, used by investors to discount the stock prices might have been much uncertain.

Fama \& French (2002) estimate the equity premium using dividends and earnings growth rates to measure the expected rate of capital gain Their estimates of the expected return based on the USA, S\&P 500 index and its relevant dividends and earnings for the period 1951 to $2000,2,55$ percent and 4.32 percent, are much lower than the equity premiums produced by the average stock return, 7.43 percent. Fama and French (2002) argue that the high average return of the stocks during this period is due to a decline in the discount rates that produce a large unexpected capital gain. The appealing message, according to Fama \& French (2002), from the dividends and earnings growth models is that the aggregate risk aversion (as measured by the Sharpe ratio for the equity premium) is on average roughly similar for the 1872 to 1949 and 1950 to 1999 periods., In contrast, the Sharpe ratio for the equity premium from the average return just about doubles from the 1872 to 1950 period to the 1951 to 2000 period. Their main conclusion is that the average stock return of the last half century is a lot higher than expected. Their research methodology is based on the premise that if the if the Dividend-price ratio, $\mathrm{D}_{\mathrm{t}} / \mathrm{P}_{\mathrm{t}}$ is stationary (mean reverting ), the compound rate of dividend growth rate approach in the long run the compound rate of capital gain. The same is applicable in the case of earning growth rate as well. They also point out that since on average during the period, the market value of equity is substantially higher, it seems safe to conclude that, on average the expected return on investment exceeds the cost of capital. If the expected return on investment exceeds the cost of capital, the average income return on book equity is greater than the estimates of the cost of capital (the expected capital stock return)

$$
\mathrm{A}\left(\mathrm{Y}_{\mathrm{t}} / \mathrm{B}_{\mathrm{t}-1}\right)>\mathrm{E}(\mathrm{R})
$$

In equation (21), the expected return $(\mathrm{E}(\mathrm{R}))$ is proxied by the dividends and earnings growth models. $\mathrm{A}$ is the average of the earnings / Book value ratio.

The interesting hypothesis for our future research thrown by Fama \& French (2002) is that the changes in expected return and discount rates are the important causes for unexpected capital gain / loss, and therefore for the volatility in stock returns. Incidental to that we will have to examine the stationarity of the dividend / stock price ratio, and the 
earning /stock price ratio. The importance of other fundamentals such as Book to Market ratios of the stocks are also highlighted.

\section{The Volatility of Prices/Inflation in the Macro- Monetary Economics}

Firstly, we discuss the effect of the variability of the prices-inflation- on the demand for money. Klein (1977) questioned the Implicit assumption in the time series studies on the demand for money functions that the quality of real money balances remain the same or time or on the assumption that the real dollar in 1870 is equal in terms of monetary services to a real dollar to a real dollar in 1970 . He introduced a quality parameter per unit of each dollar as a shift variable in the demand for money function, approximated by the variability of inflation. Klein's empirical work shows that the variability of the rate of change in prices is significant and the sign of the coefficient is positive as against the negative sign of the inflationary expectation coefficient in the demand for money function. The variability of the prices and inflation can affect the nominal and real interest rates. For example, as against the as against the standard explanation of the Gibson paradox ${ }^{4}$ of the high positive correlation of the price level and interest rates, offered by Fisher(1930) that the inflationary expectation will raise nominal interest rates on assets so that their real yields will not be affected, Harrod ( 1970) argued that the money and bonds are both financial assets and that as neither has a hedge against inflation, on account of which there is no need for the bond interest rates to rise. However, Harrod contended that the uncertainty of the variability of inflation can raise the interest rates as the people need to stay liquid if they are to be able to go more deeply into equities later on. This will raise the interest rates on bonds. On the other hand, when there is high variability of inflation, there will be a reduction in the capacity of the price system to guide the economic activities( Friedman 1977), and it will lower the economic efficiency. This will lower the investment demand, and so the real interest rates may fall. This can bias down the Fisher's inflationary expectation coefficient in the nominal interest rate equation. So, in the ultimate analysis, the impact of the variability of inflation on the nominal interest rate is an empirical question for researchers.

Levi and Makin (1979) have introduced the "Phillips curve effect "into reduced form Fisher equations. When the economy is on the Phillips curve, there will be a positive correlation between inflationary expectation and increases in output and real income. This will also raise savings for a given level of investment and hence the real interest rate will fall and this will also bias down the coefficient of the inflationary expectation in the Fisher' nominal interest rate equation. In the empirical scheme, this leads to the conjecture that in the Fisher's single equations of nominal interest rate if both the inflationary expectation and the rate increase of real income are included as arguments, when the economy is operation on the Phillips curve, the coefficient of inflationary expectation will improve to unity and the coefficient of the rate of increase of real income will attain a negative value. Paul,M.T.( 1983 ) study for India showed that the variability of inflation has a negative effect on the nominal interest rates corroborating the Friedman's hypothesis of reducing the efficiency of the economic system and the investment demand.

According to Lucas's model( 1973), the slope of the aggregate supply function depends on the on the variability of the aggregate demand function. In countries where aggregate demand fluctuates widely, aggregate price level fluctuates as well. Because most prices fluctuations in these counties do not represent fluctuations/ changes in relative prices, the suppliers do not respond to such fluctuations in aggregate prices, and therefore the slope of the aggregate supply curve will be more steep / vertical. Conversely, in countries, where aggregate prices are more stable, aggregate supply curve is less steep. Lucas (1973) tested this prediction by examining the international data on prices and output. He found that changes in aggregate demand and prices have the biggest effect on output in those countries where aggregate demand and price changes are stable.

\subsection{The Volatility in Bond Market}

Long-term bonds are fixed income assets whose prices show high volatility similar to that of stocks. Long term bonds prices fluctuate greatly in value because investors are not certain about future market values. The cash flows remain fixed; but the discount rates are uncertain, and to some extent the default rates probability also.

Some efficient market theories try to attempt these fluctuations in long term bond prices, in a similar way to the stock market. They assert that the long term rates, $\mathrm{R}_{\mathrm{t}, \mathrm{i}}$ is the optimal forecasts of its perfect foresight values or ex-post value $\mathrm{R}_{\mathrm{t}}^{*}$, the latter depends on economic variables between time, $t$, and time, $\mathrm{T}$, the maturity date. There are two simple. efficient market theories: the simple expectation theory of the term structure of interest rates, and the Fisher theory of inflationary expectations. By the simple expectation theory of the term structure, $\mathrm{R}_{\mathrm{t}}^{*}$ is a sort of average of short-term interest rates from time, $t$, until the maturity of the bond plus a small risk premium. The reason is simple : If short-term rates are much lower than the long term -rates for this period, then borrowers would not like to borrow long period. (They will not issue long-term bonds.) And instead to borrow repeatedly for short periods until the maturity. If short-term rates are expected to be much higher than long-term rates over the maturity period, then lenders would not have an incentive to lend long, to buy long term-bonds., and invest in a series of short term bonds. By the other efficient market theory, the Fisher theory, $\mathrm{R}_{\mathrm{t}}^{*}$ is a sort of the average of the expected inflation rates of short periods over the 
maturity period. The application of this Fisher hypothesis is interpreted in different ways : one, is the Fisher theory itself that the real interest rate is constant, and the nominal short rates are determined by the inflation expectation ; second explanation, following Shiller (1981b), is that the alternative to investing long term-bond is to invest in the market basket of goods. It was found in Modigliani \& Shiller (1973) that for 1956 to 1971 long-term interest rates behave similarly through time to the optimal forecast of the present value of one-period interest rates based on a simple vector-autoregressive forecasting mechanism. However, Shiller(1979) asserted that the variance of the short- term rates must be much higher than the actual sample short-term rates in order to be true for the expectation theory. Shiller has done the 'variance bound tests', and argued that the variance in the long-term bonds is much higher than in the short-term rates. Also, Shiller (1979) presented a plot of the " perfect foresight " long-term interest rate $\mathrm{R}_{\mathrm{t}}^{*}$ and the actual long-term interest rate $R_{t} . R_{t}^{*}$ looked much less variable than the actual long-term interest rate $R_{t}$. For the USA, $\mathrm{R}_{\mathrm{t}}^{*}$ Shiller had constructed as the yield to maturity at time $\mathrm{t}$ on a 25 -year coupon bond whose price is the present value of future coupons and the principal discounted by the short -term rates, plus a constant risk premium equal to the mean of $\mathrm{R}$ over sample minus the $\mathrm{r}$-short-term rate- over the sample. With these modifications the variance of $\mathrm{R}_{t}$ and $\mathrm{R}_{\mathrm{t}}^{*}$ appeared equal. It perhaps implies that the relation between the variance in short-term and long-term rate is non-linear. Further research issues, such as the stochastic process of the short-term rates (First order auto-regressive), the small sample properties of the variance of the short-term rates, conditional versus unconditional variance of the short-term and long-term rates appear to remain interesting research issues to be pursued.

Another interesting observation made by Shiller (1979) was that the spread between the long rate and short rate, i.e., the slope of the term structure gives the wrong prediction as to the short-run change in long-term interest rates. For example, when the spread between the long-term rate and the three-month rate is unusually high, the long-rate tends to fall over the next three months, rather than rise by the expectation theory. Shiller had raised some conjectures here which still remain to be resolved: are the foregoing findings due to the extraneous fads and fashions in the market for long-term bonds, causing an independent short-run noise in the long-term rates? If long rates are subject to random noise that is mean reverting, then when long rates are disturbed upward by such noise they tend to be high relative to short rates and also tend to fall subsequently. The result therefore appears to corroborate the evidence for the extraneous excess volatility of long-term interest rates. An important point missed in the existing literature on this excess volatility in the long-term bond market, in our view, is the effect of leveraging on the long -term bond markets. When investors borrowing in the short-term market, and going long(investing) in the long-term bond markets, may accentuate the volatility in the long-term markets on both occasions when the prices of long-term bonds going up and going down. The magnitude of the leveraging effect will be smaller in the short-term markets. In this respect, in our view, the volatility in the long-term bond markets may be comparable to the volatility in the equity markets due to the leveraging.

However, Shiller (1988) showed that while the problem may indeed be described in terms of mean-reverting short-run noise in the long rate relative to the optimal forecast of future short-term rates, a substantial part of this short-run noise is actually largely being described by a function of the current and lagged interest rates. It was found in that paper that the distributed lagged regression of the long rate on current and lagged short rates appears to be actually too smooth, not choppy enough, to accord with the expectation model, and the smooth distributed lag seems to be to be the source of the "wrong signals" given by the short-term interest rates. This might be a tendency of the investors to price bonds using their memories, and to blur the past history of short-term interest rates. But this is a departure from market efficiency, and is factually different from the interpretation of excess volatility and fashions and fad story about long-term rates. This is an area of research where more work is needed.

However, Campbell, J.\& Shiller (1984) found that the long-short spread behaves quite similarly to the optimal forecast of the present value of future short-term rates. The estimation was based on vector- autoregressive model of interest rates. This can be represented by plotting $R_{t}-r_{t}$ and $R_{t}^{*}-r_{t}$. The distributed lag model generates $R_{t}^{*}$ series .

$R_{t}^{*}-r_{t}$ is indeed more volatile than $R_{t}-r_{t}$. When $R_{t}^{*}-r_{t}$ is regressed on $R_{t}-r_{t}$ (term-structure spread), and a constant term, the coefficient of $R_{t}^{*}-r_{t}$ is significantly greater than zero. These finding corroborate the expectation theory of the term-structure. But Campbell, J. \& Shiller (1984) concluded with post-World War ii data that long rates tended to underreact in a sense to short rates. Using the same method, Shiller (1987) found that long rates overreacted to short rates before the World -War II.

Testing the efficient market hypothesis of the term-structure theory through the Fisher equation and putting the expected inflation rates or the actual short term inflation rates, assuming the rational expectation theory to explain long-term bond rates, has its own problems of finding an appropriate inflationary expectation model .We had discussed the Fisher hypothesis in section 4.1, and we are not discussing it here in length.

\subsection{Issues on Spot and Futures Market Returns Volatility and the Linkages}

There has been an old thinking that the futures markets make the spot markets more volatile. However, there has not been much strong empirical support for it. Pure finance theory states that spot and futures volatility should be similar 
when a theoretical no-arbitrage condition ties the future prices to the spot prices via the operations of the cost of carry principle, etc. The two volatility figures should be identical, in theory, when price changes (returns) are uncorrelated and the real dividend yield is constant (Adesi,B., \& Whaley 1987).This result holds regardless of the final settlement date of the futures contract. However, Samuelson (1976) argued that the volatility of futures prices should increase as the contract approaches expiration. In his analysis Samuelson assumed that competitive forces in the futures market keep the futures prices at a level equal to the expected future spot prices at the contract termination. The spot prices follow a stationary process and prices changes are uncorrelated. Price changes are large when more information about the expected price of a commodity is being revealed. Later as the contract nears maturity, the rate of information acquisition increases. Virtually many studies agree that futures prices have seasonal volatility. Thus, Samuelson's hypothesis asserts a particular kind of seasonal volatility. Volatility itself can be autocorrelated. There can be Day effect, Week effect etc. Kawaller, Scott, \& Koch $\left(1999^{b}\right)$ found mid-day volatility spikes in U.S futures markets.

The issue of information transmission between spot and futures markets is of interest to researchers in Finance and policy makers. An empirical investigation of this issue commonly focuses on the price discovery and volatility spillovers. Price discovery is the process by which a market (usually futures market) reflects new information before another related market (usually spot market). The futures market as the information provider and the leading role of it over spot market is based on the assumption of more transaction costs, and the restriction on short sales in spot markets and the higher degree of leverage that can be used in futures market. If the futures prices contain information about spot prices, arbitrage opportunities exist (Floros \& Vougas 2008). Several studies broadly find that price discovery appears first in futures market and is then transmitted to the spot market (Herbst, McCormack, \& West 1987), (Kawaller, Koch, \& Koch 1990ª), (Chan, Chan, \& Karolyi 1991),( Chan 1992), (Ghose 1993),( Lien \& Tse 2002), ( Yang., Balyeat., \& Leatham 2001), (Raju \& Karande 2003). This price discovery function implies that prices in the futures and spot markets are systematically related in the short run and/or in the long run. Empirical studies find that futures returns lead spot returns (Ng. 1987), (Kawaller, Koch, \& Koch $1987^{\circ}$ ), (Stoll \& Whaley 1990), (Floros \& Vougas 2008). Hernandez \& Torero (2010) examine the dynamic relationship between spot and futures prices of agricultural commodities. Their Granger causality results indicate that spot prices are generally discovered in futures markets. In particular, they find that changes in future prices lead changes in spot prices more often than the reverse. Zakaria \& Shamsuddin (2012) have found, through Granger causality tests for Malaysia, that the direction of causality is unidirectional from cash markets to futures markets, and concluded that spot market plays the role as price discovery vehicle instead of futures market. However, they have found that long run equilibrium relation - cointegration-exists between spot and future market. Their interpretation of the finding is that in Malaysia future market is in nascent stage and therefore the dominance of futures market is absent in Malaysia.

However, the efficient market hypothesis is invoked by some researchers (Lean, McAleer, \& Wong 2010) and their research showed that based on West Texas Crude Oil prices spot and futures data for the period 1989-2008, there is no evidence of any mean-variance (MV), and Stochastic dominance (SD) relationship between oil spot and futures prices. From the aforesaid finding, they conclude that there is no arbitrage opportunity between spot and futures markets, and investors are indifferent in investing between spot and futures oil markets, and the markets are efficient.

In the cointegration jargon, the price discovery function implies the presence of an equilibrium relation binding the two prices together. (Sakthivel, P. \& Kamaiah, B. (2010). If a departure from equilibrium occurs, prices in one or both markets should adjust to correct the disparity. Cointegration means that even if the spot and futures prices may move randomly, the long-term trends in one market prices can affect the other market's changes in prices or the returns in the other market, and the causality will be valid, at least in one direction, which is tested through the error-correction models. This, naturally raises the doubt that price discovery from one to another market may exist. at least in one direction, if cointegration is established and arbitrage opportunities may occur. However, even if there is cointegration, the changes in prices or the return in one market need not necessarily be correlated with the changes in prices or return in the other market. But they can be correlated as well. Nevertheless, even if arbitrage opportunities exist sometimes, why not still markets cannot be efficient and a long run equilibrium relation cannot occur? These unresolved issues have given scope for much empirical work. The time length differences between long- term trends and short run changes depends on the data structure the researcher uses for cointegration analysis.

Herbst, McCormack, \& West (1987) argue that futures market is commonly observed for updated price more frequently than the spot market. Investors with strong beliefs about the direction of market, trade in futures rather than spot, because of low transaction cost and high degree of leverage. Such trading, moves futures first and pulls spot price by means of arbitrage, creating a lead-lag relation. Considering the relation between futures and spot price, Kawaller, Koch, \& Koch (1990) $)^{\mathrm{a}}$, put forward the general principle that spot price is affected by past spot price, current and past futures price and other market information. Similarly, futures price is affected by past futures price, current and past spot price and other market information. Thus, causality is likely to be bidirectional. They further argued that the lead-lag pattern between futures and spot prices changes as new information arrives. Each may lead the other as market participants 
shift information for clues that are relevant to their position which may be spot or futures. Wu, Li, \& Zhang (2005) examine information transmission between the S\&P 500 and FTSE 100 index futures and find that the volatility of US market is affected by the most recent volatility surprise in the UK market.

The second direction investigates volatility spillover between spot and futures markets. Volatility spillover hypothesis posits "if volatility spillovers are combined with asymmetries, a bad news shock in either market may increase volatility and its persistence in both markets "(Tao \& Green 2012). The aforementioned authors (Tao \& Green 2012) find significant volatility asymmetries in both the FTSE 100 cash and stock index futures prices. There are some other studies also which have examined this issue (for instance (Koutmos \& Tucker 1996), (Fleming, Kirby, \& Ostdiek 1998) It has been argued that volatility surprises in one market will spillover to volatility in another market, in a subsequent trading period. Recently, Antonakakis, Kizys, and Floros (2014) employ a newly introduced spillover index to examine spillovers between spot and futures market volatility, volume of futures trading and open interest in the UK and the US. They find that spot and futures volatilities in the UK (US) are net receivers (net transmitters) of shocks to volume of futures trading and open interest. Further their study showed that the spot and futures volatility spillovers between the UK and US markets are of bidirectional nature, however, they are affected by major economic events such as the global financial and Eurozone debt crisis.

Milunovich \& Joyeux (2010) examine the issue market efficiency and price discovery in the European Union carbon futures market. Their findings suggest that none of the three carbon futures contracts are priced according to the cost-of-carry model, although two of the three contracts form a stable long-run relationship with the spot price and interest rates, and hence act as adequate risk mitigation instruments. They further observe that the predominant source of information spillovers appears to be the sign or direction of price change, i.e. return spillover rather than the magnitude of price changes, i.e. volatility spillover.

Reichsfeld \& Roache (2011) assess the spot price forecasting performance of 10 commodity futures at various horizons up to two years. They find that, out-of-sample, the forecasts from futures market is hard to beat, and that the forecasting performance of futures does not depend on the slope of futures curve, in contrast to the predictions of well-known models of commodity markets. They also find that futures' market forecasting performance to be invariant to whether prices are in an upswing or downswing, during periods of futures market in backwardation or contango.

Khan (2006)'s study of the Pakistan stock markets supports the hypothesis that spot prices generally lead the futures prices in incorporating new information, and that the volatility in the futures market does not increase the volatility in spot markets, and on the contrary, supports the alternative hypothesis that volatility in the futures market may be the outcome of the volatility in the spot markets. This in a way corroborates Samuelson's hypothesis that shocks in spot markets will increase the volatility of the futures prices as they near expiration.

An extensive survey of this literature has been done in (Paul, M.T. \& Kimatta, J. (2016)

\section{Issues for Research}

(1) Is the magnitude of the volatility in the spot and futures market not similar.? The alternative hypothesis is that it is similar. If the magnitude of the volatility is similar, and if returns are not correlated, the markets are believed to be very efficient. This hypothesis testing will either reinforce or clear the thinking among some policy makers that the introduction of the futures market will increase the volatility in the spot market. If the introduction of the futures market will increase the volatility in spot markets, and if the futures markets volatility is higher than that of spot market because of the higher leverage effects and low transaction costs in futures markets, policy makers may sometimes be misled to discourage to introduce and develop futures markets.

(2)A related issue is. if the introduction of the derivative markets, and margin trading has increased the volatility in the spot stock markets. The margin trading and the derivative markets will increase liquidity in the markets and therefore can reduce the volatility in the spot markets ; but on the other hand, the margin trading, and the introduction of derivative markets will increase the leverage and they may lead to a situation when the investor may sell in a falling market, and can exacerbate the volatility.

(3) Is the volatility in the spot and future market returns not persistent.? The alternative hypothesis is that it is persistent. This hypothesis is tested by researchers through the significance of the $\mathrm{ARCH}$, and $\mathrm{GARCH}$ parameters in modeling the returns in the spot and futures market. Apart from the econometrics of the volatility modeling, as they are related to the returns of the spot and futures market, it has implications for finance theory that the expected returns are much associated with the risk proxy, i.e., the volatility of the returns.

(4) Another important issue is the information efficiency in the financial markets, at least from a weak form efficient market hypothesis perspective (Fama 1970), that is to study short memory process which involves mean reversion in the return of the spot and futures market versus a long memory process which involves distancing from the mean return and no reversion to the mean returns. In terms of precise hypothesis formulation, they can be stated in the following ways: 
(A) The Returns do not follow an $\mathrm{ARCH}(1$,$) process / alternative is that returns follow an \mathrm{ARCH}(1$,$) process. If the$ returns follow an $\mathrm{ARCH}(1$,$) process, returns are highly autocorrelated, and have long memory, and markets are not$ informational efficient from the weak form efficiency angle.(B) The Returns do not follow a $\operatorname{GARCH}(1,1)$ process/ alternative is follow a $\operatorname{GARCH}(1,1)$ process. If the returns follow a $\operatorname{GARCH}(1,1)$ process, the returns are not autocorrelated, it involves a 'short memory 'and there is mean reversion, and therefore financial markets are informational efficient from the weak form efficient market hypothesis (Fama 1970). Further, it can indirectly support Samuelson's hypothesis of the stationarity of the returns in financial markets, and the changes in the return can be random. Having said that if the returns autocorrelations decay faster, it supports the efficient market hypothesis, we are aware that there are occasions where the conditional expected returns could depend on previous returns because the asset's risk premium follows a stationary autocorrelated process, and still the efficient market hypothesis can hold. We have to test $\mathrm{ARCH}(\mathrm{M})$ models to verify to know if the asset's risk premiums follow a stationary auto correlated process.

(5) Another issue in volatility research is whether the bad news, i.e., negative shocks will not have / alternative will have, bigger impact on the volatility in spot and futures market. The positive and negative shocks will have different impact on the volatility in financial markets. This phenomenon of the dominance of the negative news on volatility is also explained through 'the leverage effect' in finance literature, as the bad events reduce the equity values, and therefore the debt/equity ratio increases, and this increases the risk and volatility. If the foregoing is correct, the adverse effects of the US financial crisis, rather than its positive effects if any, will increase the risk and volatility. This information would be highly useful to policy makers.

A related issue is if the specific events such as US financial crisis cannot / alternative can, impact the persistence in volatility. The US financial crisis produced more negative shocks than positive shocks and the negative effects might have significant effects on volatility in spot and futures markets.

(6) The important issues are the market efficiency, arbitrage, the price discovery and the volatility spillover between spot and futures market. The aforesaid issues can be addressed employing two research strategies: The GARCH variances from spot market can be used as another independent variable in explaining the return in futures market, and the GARCH variances from futures market is to be used as another independent variable in explaining the returns in the spot market. The second method of testing the spillover effects is to use the Granger's causality tests between the GARCH variances of spot and futures market. The hypothesis is that the GARCH variances in spot market do not Granger cause the GARCH variance in futures market. The alternative is it does Granger cause. There may be either unidirectional or bidirectional causality. If a bidirectional causality is proved, neither market is dominant over the other. If the spot and futures market is linked through aforesaid ways, it supports the price discovery, market efficiency, and the no arbitrage possibilities. (Paul, M.T.\& Kimatta, J.2016).

(7) The volatility in the stock markets, the world over, has been relatively less since the global financial crisis in 2008 until now, 2018 January, in terms of the average correction percent of various stocks. And the markets have been booming. Is it due to low interest rates and excess liquidity in major economies in the world? Is average correction a right measure of volatility as it may ignore the upward movements? (Ruchir S. 2018). But assuming his measure of average correction of the market is a reasonable good measure of volatility, can this lower volatility lead to future excess volatility in the world stock markets?

(8) The Dividend - price ratio, $\mathrm{D}_{t} / \mathrm{P}_{\mathrm{t}}$ is stationary and therefore the growth rate of the dividend can be a proxy for expected capital gain of the stock (Fama and French 2002)

The same hypothesis can be tested for earning - price ratio also.

(9) The decline in expected return/ discount rate, is the major cause for the unexpected stock returns during the half of the past century, and hence the volatility in stock prices. (Fama and French 2002) The same can be tested for this century also for about 17 years. Incidental to the foregoing hypothesis, is the hypothesis that the return on investment, proxied by average of the earning to book value of the equity, is greater than the cost of capital (Equation no.12). Risk aversion as measured by the Sharp ratio for equity premium for the last century remains more or less constant; but the risk ratio for the average returns from the stock increases in the latter half of the previous century.

(10) The information about major disasters affect the stock market volatility.

(11) The variance of, $p_{t}$ real stock price index (detrended by dividing by a factor proportional to long run exponential growth path) is less than that of the $\mathrm{p}_{\mathrm{t}}{ }^{*}$ is the present discounted value of the actual subsequent real dividends, (variance inequality is satisfied), and efficient market model is corroborated.

(12) That high sample kurtosis does not does not necessarily indicate infinite variances and instead suggests that the existence of moments for the price series is implied by the existence of moments for the dividends series (Shiller 1981a) 
(13) The inflationary expectation will raise nominal interest rates (Fisher 1930)

(14) The variability of inflation will raise the nominal interest rates (Harrod 1970); The variability of inflation will reduce the real interest rates and therefore nominal interest rates may also decrease. (Friedman 1977)

(15) In countries where is high variability of inflation and aggregate demand, the aggregate supply curve will be steeper than in other countries. (Lucas 1973)

(16) Does the simple expectation theory of the term structure of interest rate predict well that the long-term interest rate, $\mathrm{R}_{\mathrm{t}}^{*}$ is a sort of average of short-term interest rates from time, $\mathrm{t}$, until the maturity of the bond, $\mathrm{T}$, plus a small risk premium?

(17) How the higher variance in the long-term interest rates than the variance in the average short-term rates, is not easy to be explained in the context of the variance-bound test condition that the variance of both should equal and to be consistent with the efficient market hypothesis. (Shiller1979)? One explanation that we have offered in this critical survey paper is that the higher variance in the long-term rates may be due to the leverage effects dominant in the long-term rates.

(18) Can the efficient market hypothesis of explaining the variations in long-term interest through the averages of short term-inflation rates, through Fisher effect, be tested? One immediate issue in testing the aforesaid is the limitation that the rational expectation in forming inflationary expectations by people, should be assumed without a test!

\section{Conclusions}

The average returns in the stock markets in the last fifty years of the previous century is much higher than the expected return based on the dividends premium or the growth rate of dividends. The average expected return on investment, earning to book value ratio, exceeded the cost of capital. Therefore, one reason for the increased volatility in the last fifty years of the previous century, might be the changes in the expected return and the discount rates. But in the present century, after the global financial crisis in 2008 , the volatility in stock markets has decreased and financial wealth has increased in the world over. However, testing and explaining the efficient market model in the long-run, through linking the actual stock price index, and the theoretical proxies through real dividend growth index, and through the variance bound tests, still remain the research issues.

The volatility in financial markets involves the conceptual and empirical issues regarding the financial asset's returns and volatility both unconditional and conditional volatility. The volatility in financial markets is linked to the risk modeling of the asset returns, and some varieties of the empirical conditional volatility of the returns such as GARCH (1.1) models will throw light on not only the modeling of the risk but also the answers to the questions of the efficiency in financial markets. The returns are correlated or not, is an important research issue to resolve informational efficiency question in spot and futures markets. The magnitude of the volatility in spot and futures market for the same commodity is of interest for policy makers. In short, the important issues are the market efficiency, arbitrage, the price discovery and the volatility spillover between spot and futures market.

As the finance theory tells us that the objective of investment is consumption, and also to find the present value of the future cash flows of all assets -equities, bonds, and physical assets - the market rate of interest is important, the macro-monetary economics of interest rate and inflation rate changes are relevant. In macro- monetary economics, the variability of inflation, as a variable is suggested to explain the demand for money functions, and the effect of inflationary expectation on the nominal interest rates, given the variability of inflation as an argument in the function to make constant the effects of the positive or negative effect on the nominal interest rates, and to refine the order of the magnitude of the inflationary expectation coefficient on the nominal interest rates.

The volatility in the market for interest rates, especially the bond market volatility, is also very important research issue, and the efficient market perspective is applied and tested in the literature through testing the term-structure theories of interest rates, and also the variance bound tests linking the variance in the long-term rates to the variance in the average short-term rates. The challenge is to explain the higher variance in the long-term rates. We have tried to explain, in this survey paper, that the higher variance in the long-term rates, may be the leverage effect are more dominant in the long-term rates than in the short-term rates.

We, therefore, conclude that the variability of the financial asset returns such as that of stocks and bonds, and that of nominal interest rates and the variability of the inflation are both very important theoretical and empirical issues for research in Financial markets and Finance, and Macro- monetary economics. The limitation of this survey on volatility literature, is that it has focused on the volatility literature in the financial markets, especially that of the stock market, the bond market, and the market for the demand for money and interest rates, but not touched the volatility in the foreign exchange markets, and not even the real asset markets, as otherwise the survey may become too lengthy and unwieldy. 


\section{Acknowledgements}

The author would like to thank and acknowledge the useful suggestions from the editor and editorial staff, and the learned referees for the useful suggestions, without implicating them for any errors and omissions in this paper.

\section{Notes}

Note 1. In some studies standard deviation or logarithm of variance is used in the return equation

Note 2. Glosten L R, R Jagannathan and D.E Runkle (1993) provide a brief overview of the conflicting results in the literature and then explained why both positive and negative relationship between returns and volatility would be consistent with theory.

Note 3. Estimating the Nelson model under the assumption of normally distributed errors yields identical estimates to those reported by Eviews excepting the intercept term which will differ by $\alpha \sqrt{\frac{2}{\pi}}$

Note 4. Gibson Paradox. Gibson Paradox is the high correlation between the level of prices and the level of nominal interest rates. There is no apparent economic logic when the money supply and prices both increased in the same proportion, the nominal interest rates to go up. But this paradox is explained by Irving Fisher through the positive effect of inflationary expectation on nominal interest rates.

\section{References}

Adesi, B., \& Whaley, R. F. (1987). Efficient Analytic Approximation of American Option Values. The Journal of Finance, 42(2), 301-320. https://doi.org/10.1111/j.1540-6261.1987.tb02569.x

Anotonakakis, N., Kizya, R., \& Floros, C. (2014). Dynamic Spillover Effects in Futures Markets., MPRApaper 53876, University Library of Munich., Germany.

Bhattacharya, B., \& Roy, T. N. S. (2009). Volatility and forecasting of BSE bankex. Journal of quantitative economics, $7(1), 60-77$.

Black, F. (1976). Studies of the Stock price volatility changes. Proceedings of the American Statistical Association, Business and Economics Statistics, 177-181.

Bollerslev, T., \& Jeffrey, M. W. (1992). Quasi-maximum Likelihood Estimation and Inference in Dynamic Models with Time-varying covariances. Econometric Reviews, 11(2), 143-172. https://doi.org/10.1080/07474939208800229

Bollerslev, T., Chou, R. Y., Kroner, K. F. (1992). ARCH modeling in finance: A review of the theory and empirical evidence. Journal of Econometrics, 52(1-2), 5-59. https://doi.org/10.1016/0304-4076(92)90064-X

Brock, W., \& LeBaron, B. (1996). Adynamic structural model for stock market volatility and trading volume. Review of Economics and Statistics, 78, 94-110. https://doi.org/10.2307/2109850

Campbell, J. Y., \& Shiller, R. J. (1984). A Simple Account of the Behavior of Long-Term Interest Rates. American Economic Review, 74, 44-48.

Campbell, J. Y., \& Hentschel, L. (1992). No News is Good News: An asymmetric model of Changing Volatility in Stock Returns. Journal of Financial Economics, 31(3), 281-318. https://doi.org/10.1016/0304-405X(92)90037-X

Chan, K., Chan, K. C., \& Karolyi, G. A. (1991). Intraday Volatility in the stock index futures market. Review of Financial Studies, (4), 657-684. https://doi.org/10.1093/rfs/4.4.657

Chan, K. (1992). A Further Analysis of the Lead Lag Relationship Beween the Cash Market and Stock Index Futures Market. Review of Financial Studies, 5(1), 123-152. https://doi.org/10.1093/rfs/5.1.123

Chin, W. C., Lai., N. S., Mohmad, Y. N. A., \& Ying, K. C. (2012). Asymmetric Fractional Integrated Volatility Modeling of Asian Equity Markets under the subprime Mortgage Crisis. Journal of Quantitative Economics, 10 (1),70-84.

Christie, A. A. (1982).The stocastic behavior of Common stock variance value, leveraage, and interest rates effects. Journal of Financial Economics, 56(10), 407-432. https://doi.org/10.1016/0304-405X(82)90018-6

Crockett, A. (1997). The Theory and Practice of Financial Stability. in International Finance Section Department of Economics, Princeton University.

Reichsfeld, D. A., \& Roache, S. K. (2011). Do Commodity Futures forecast better spot prices. IMF Working Paper, November: $W P / 11 / 254$.

Davis, E. (1996). The Role of Institutional Investors in the Evolution of Financial Structure and Behavior. Paper presented at the Conference on the Future of Financial System, Sydney, Reserve Bank of Australia, July, 8-9. 
Engel, R. F., Lilien, D. M., \& Robins, R. P. (1987). Estimating Time Varying Risk Premia in the Term Structure: The ARCH-M model. Econometrica, 55(2), 391-407. https://doi.org/10.2307/1913242

Engle, R. F., \& Ng, V. (1993). Measuring and Testing the impact of News on Volatility.Journal of Finance, 43(5), 1749-1778. https://doi.org/10.1111/j.1540-6261.1993.tb05127.x

Fama, E. (1970). Efficient Capital Markets :A Review of Theory and Empirical Work. Journal of Finance, 25(2), 383-417. https://doi.org/10.2307/2325486

Fama, E. F., \& French, K. R. (2002). The Equity Premium. The Journal of Finance, LVII(2), 637-659. https://doi.org/10.1111/1540-6261.00437

Fleming, J., Kirby, C. D., \& Ostdiek, B. (1998). Information and Volatility Linkages in the Stock,bond and Money markets. Journal of Financial Economics, 49(1), 111-137. https://doi.org/10.1016/S0304-405X(98)00019-1

Floros, C., \& Vougas, D. V. (2008). The Efficiency of Greek Stock Index Futures Market. Managerial Finance, 34(7), 498-519. https://doi.org/10.1108/03074350810874451

Fisher, I. (1930). The Theory of Interest. New York, Macmillan.

Friedman, M. (1977). Inflation and Unemployment. Journal of Political Economy, 85(3), 451-472. https://doi.org/10.1086/260579

Gallant, A. R. P. E., Rossi, \& Tauche, G. E. T. (1992). Stock Prices and Volume. Review of Financial Studies, 5, 199-242. https://doi.org/10.1093/rfs/5.2.199

George, M., \& Joyeux, R. (2010). Market Efficiency and Price Discovery in the European Union Carbon Futures Market. Applied Financial Economics, 20(10).

Ghose, A. (1993). Cointegration and Error Correction Models : Intertemporal Causality Between Index and Futures Prices. Journal of Futures Markets, 13(2), 193-198. https://doi.org/10.1002/fut.3990130206

Glosten, R., \& Jagannathan, R., \& Runkl, D. E. (1993). On the relation between the Expected Value and Volatility of the Nominal Excess returns on Stock. The Journal of Finance, 48(5), 1779-1801. https://doi.org/10.1111/j.1540-6261.1993.tb05128.x

Harrod, R. (1971). Discussion Paper on on Friedman's ' A Monetary Theory of Nominal Income, 'in : G.Claton and J.C. Gilbert edited 'Monetary Theory and policy in the 1970s '. Oxford University Press, Oxford.

Hernandez, M., \& Torero, M. (2010). The dynamic relationship between spot and futures prices of agricultural commodities International Food Policy Research Institute, Discussion Paper 00988,June.

Herbst, A. F., Mc Cormack, J. P., \& West, E. N. (1987). Investigation of a lead-lag relationship between spot stock indices and their futires contracts. Journal of Futures Market. (7), 373-381. https://doi.org/10.1002/fut.3990070403

Joshi, P. (2010). Modeling Volatility In Emerging Stock Markets of India and China. Journal of Quantitative Economics, 8(1), 86-94.

Kapil, C., \& Bajaj, S. ( 2012). Intraday Lead/Lag Relationship Between the Futures and Spot Market. Eruasian Journal of Business and Economics, 5(9), 165-186.

Karmakar, M. (2009). Price Discoveries and volatility spillovers in S\&P CNX Nifty Future its underlying Index CNX Nifty, Vikalpa, 34(2), 41-56. https://doi.org/10.1177/0256090920090204

Karpoff, J. M. (1987). The relation between price changes and trading volume : A Survey. Journal of Financial and Quantitative Analysis, 22, 109-126. https://doi.org/10.2307/2330874

Kawaller, I. G., Scott, D., \& Koch, P. D. (1987). The Temporal Price Relationships between S\&P 500 Futures and the S\&P 500 Index. The Journal of Finance, 42(5), 1309-1329. https://doi.org/10.1111/j.1540-6261.1987.tb04368.x

Kawaller, I. G., Koch, P. D., \& Koch, T. W. (1990). Intraday Relationships Between Volatility in S\&P 500 Futures Prices and the S\&P 500 index. Journal of Banking and Finance, (14), 373-397. https://doi.org/10.1016/0378-4266(90)90055-7

Kawaller, I. G., Scott, D., \& Koch. P. D. (1999). Mid-Day Volatility Spikes in U.S. Futures Markets. The Journal of $\begin{array}{lrrr}\text { Futures } & \text { Markets, } & 19(2), & 195-216 .\end{array}$ https://doi.org/10.1002/(SICI)1096-9934(199904)19:2<195::AID-FUT4>3.0.CO;2-C

Khan, S. (2006). Role of futures market on volatility and price discovery of the spot market: Evidence from Pakistan's stock market. Lahore Journal of Economics, 11(2), 107-121. 
Koutmos, G., \& Tucker, M. (1996). Temporal relationship and dynamic interactions between spot and future stock $\begin{array}{llll}\text { markets. Journal of } & \text { Futures }\end{array}$ https://doi.org/10.1002/(SICI)1096-9934(199602)16:1<55::AID-FUT3>3.0.CO;2-G

Klein, B. (1977). The demand for Quality adjusted cash balances :Price uncertainty in the U.S demand for money functions. Journal of Political Economy, 185, 691-715. https://doi.org/10.1086/260596

Krugman, P. (1991). Financial Crisis in the International Economy in Martin Feldstein,ed., The Risk of Economic Crisis, Chicago, University of Chicago Press, 85-109.

Lean, H. H., McAleer, M., \& Wong, W. K. (2010). Market Efficiency of Oil Spot and Futures :A Mean Variance and Stochastic Dominance Approach. Kyto Institue of Economic Research, Discussion Paper, 718.

LeRoy, S., \& Porter, R. (1981). The Present Value Relation: Tests Based on Implied Variance Bounds. Econometrica 49, 555-574. https://doi.org/10.2307/1911512

Levi, M. D., \& Makin, J. H. (1979). Fisher, Phillips, and Friedman and the measured impact of inflation on interest rates. Journal of Finance, 34(2). https://doi.org/10.1111/j.1540-6261.1979.tb02069.x

Lien, D., \& Tse, Y. K. (2002). Some Recent Developments in Futures Hedging. Journal of Economic Surveys, 16(3), 357- 396. https://doi.org/10.1111/1467-6419.00172

Ling, S., \& McAleer, M. (2002a). Necessary and Sufficient Moment Conditions for the GARCH(r,s) and Asymmetric Power GARCH(r,s) Models.Econometric Theory, 18(3), 722-729.

Ling, S., \& McAleer, M. (2002b). Stationary and Existence of Moments of a Family of GARCH(r,s) Processes..Journal of Econometrics, 106(1), 109-117.

Linter, J. V. (1956). Distribution of Incomes of Corporations among Dividends, Retained Earnings, and Taxes. American Economic Review, 46, 97-113.

Lucas, R. (1973). Some international evidence on output-inflation tradeoffs. American Economic Review. 63(3), 326334.

Mankiw, N. G., Romer, D., \& Shapiro, M. D. (1989). Stock Market Efficiency and Volatility : A Statistical Appraisal reproduced from Harvard University Press, Harvard. https://doi.org/10.3386/w3154

Mahalik, M., \& Acharya. K., et al. (2009). Price Discovery and volatility spillovers in Futures and Spot commodity markets: Some Empirical Evidence from India. Proceedings from : The Fourth Annual International Conference on Public Policy Management. http://www.igidr.ac.in/pdf/publication/pp-062-10pdf

Mallikarjunappa, T., \& Afsal, E. M. (2010). Price Discovery Process and volatility Spillovers in Spot and Futures Markets: Evidence from Individual Stocks. Vikalpa, 35(2), 49-62. https://doi.org/10.1177/0256090920100205

Marsh, T. A., \& Merton, R. C. (1987). Dividend Behavior for the aggregate stock market. Journal of Business, 60, 1-40. https://doi.org/10.1086/296383

Modigliani, F., \& Shiller, R. J. (1973). Inflation, Rational Expectations,and the Term Structure of Interest Rates. Economica, 40, 12-43. https://doi.org/10.2307/2552679

Milunovich, G., \& Joyeux, R. (2010). Market Efficiency and Price Discovery in the EU Carbon Futures Market (May 28, 2007). Applied Financial Economics, 20(10), Also available at SSRN: https://ssrn.com/abstract=989272

Namita, R., Ruhi, K., \& Batra, G. ( 2013). Futures Trading and its impact on Volatility of Indian Stock Market.. Asian Journal of Finance and Accounting, 5(1).

Nelson, D. B. (1991). Conditional Heteroskedascity in Asset Returns: An New Approach. Econometrica, 59(2), 347-370. https://doi.org/10.2307/2938260

Ng, N. (1987). Detecting Spot Prices Forecasts in Futures Prices Using Causality Tests. Review of Futures Markets. $6(1), 61-89$.

Nikolas, A., et al. (2014). Dynamic Spillover Effects in Futures markets. MRPA Paper No.53876 posted (5) March 01-08-UTC.

Padhi, P. (2006). Persistence and Asymmetric Volatility in Indian Stock Market. Journal of Quantitative Economics, 4, 103-113.

Pati, P. C., \& Chandra, P. P. (2009). Information, Price Discovery and Causality in the Indian Stock Index Futures Market. IUP Journal of Financial Risk Management, 6(3\&4), 7-21. 
Paul, M. T. (1981). The Demand For Money And The Variability of Inflation in India ( India $1951-52$ to 1977 -78. The Indian Economic Journal, 29(1), 65-74.

Paul, M. T. (1984). Interest Rates And The Fisher Effect In India - An Empirical Study. Economics Letters, 14, 17-22. https://doi.org/10.1016/0165-1765(84)90022-3

Paul, M. T., \& Kimatta, J. (2016). The Linkages, Persistence, Asymmetry In The Volatility and the Effect Of the US Subprime Mortgage Financial Crisis On the Spot and Futures Market Returns In Indian Stock Market. The Applied Economics, 48(8), 669-683. https://doi.org/10.1080/00036846.2015.1085641

Poon, S. H., \& Granger, C. (2003). Forecasting Financial Market Volatility: A review. Journal of Economic Literature, 41(2), 478-539. https://doi.org/10.1257/.41.2.478

Pradhan, K. C., \& Bhat, S. K. (2009). An Empirical Analysis of Price Discovery, Causality and Forecasting in the Nifty Futures Markets. International Research Journal of Finance and Economics: Retrived from hiip://ww Do Commodity w.eurojournals.com/irjfe_26_07.pdf

Raju, M. T., \& Karoande, K. (2003). Price Discovery and Volatility on NSE futures Market. SEBI Bulletin, 1(3), 5-15.

Raymond, S. W., \& Yiuman, T. (2004). Price Discovery in the Hang Seng Index Markets: Index, Futures, and the Tracker Fund. Journal of Futures Markets, 24(9), 887-907. https://doi.org/10.1002/fut.20112

Reichsfeld, D. A., \& Roache, S. K. (2011). Do Commodity Futures Help Forecast Spot Prices. IMF Working Papers. No11/254. https://doi.org/10.5089/9781463923891.001

Ruchir S. (2018). Top Ten Trends of 2018. Retrived from https://www.ndtv.com/opinion/digital-detox-bitcoin-and-other-trends-for-2018-by-ruchir-sharma-1796917?pfrom =home-opinion

Sakthivel, P., \& Kamaian, B. (2010). Price Discovery and Volatility Spillover Between Spot and Futures Markets : Evidence from India. Journal of Applied Economics, 9(2), 81-97.

Samuelson, P. A. (1976). Is the Real World Price a tale told by the idiot of chance?. Review of Economics and Statistics. 58(1),120-123. https://doi.org/10.2307/1936018

Scharfstein, D. S., \& Stein, J. C. (1990). Herd Behavior and Investment. American Economic Review, 80, 465-479.

Schwert, G. W. (1987). The Causes of Changing the Stock Market Volatility. Reproduced from the University of Rochester.

Schwert, G. W. (1989). Why does stock market volatility change over time. Journal of Finance, 44(11), 1115-1153. https://doi.org/10.1111/j.1540-6261.1989.tb02647.x

Sharpe, W. F. (1964). Capital Asset Prices: A Theory of Market Equilibrium Under Conditions of Ris. The Journal of Finance, 19(3), 425-442.

Shiller, R. J., \& Franco, M. (1979). Coupon and Tax effect on New and Seasoned Bond Yields and the measurement of Debt Capital, Journal of Financial Economics, 7, 297-318. https://doi.org/10.1016/0304-405X(79)90017-5

Shiller, R. J. (1981a). Do Stock Prices Move Too Much to Be Justified by Subsequent Changes in Dividends? American Economic Review 71, 421-435.

Shiller, R. J. (1981b). Alternative Tests of Rational Expectations Models: The Case of the Term Structure. Journal of Econometrics, 16, 17-87. https://doi.org/10.1016/0304-4076(81)90076-2

Shiller, R. J. (1985). Financial Markets and Macroeconomic Fluctuations. in James. L.Butkiewicz. et al.,eds., Keynes Economic Legacy, New York: Praeger.

Shiller, R. J. ( 1988). A Scott-Type Regression Test of the Dividend Ratio Model. Reproduced from Yale University.

Stoll, H. R., \& Whaley, R. E. (1990). The Dynamics of Stock Index and Stock Index Futures Returns. Journal of Financial and Quantitative Analysis. 25(04), 441-468. https://doi.org/10.2307/2331010

Tao, J., \& Green, C. J. (2012). Assemetries, Causality and Correlation Between FTSE 100 spot and Futures: A DCC-TGARcH-M Analysis. International Review of Financial Analysis, 24(C), 26-37. https://doi.org/10.1016/j.irfa.2012.07.002

Timmermann, A. (2001). Structural breaks, incomplete information and Stock prices. Journal of Economics and Business Statistics, 19, 299-314. https://doi.org/10.1198/073500101681019954

Wu, C., Li, J., \& Zhang, W. (2005). Intradaily peridicity and volatility spillover beween International Stock Index futures Markets.Journal of Futures Markets, 25(6), 553-585. https://doi.org/10.1002/fut.20155 
Yang, J., Balyeat, R. B., \& Leatham, D. J. (2001). Futurs Trading Activity and Commodity Price Volatility. Journal of Business Finance \& Accounting, 32(1).

Zakaria, Z., \& Shamsuddin, S. (2012). On the Relationship Between Stock Market Volatility and the Macroeconomics Volatility. Journal of Business Studies Quarerly, 4(2), 61-71.

Zakoian, J. M. (1994). Threshold Heteroskadastic Models. Journal of Economic Dynamics and Control, 18(5), 931-955. https://doi.org/10.1016/0165-1889(94)90039-6

\section{Copyrights}

Copyright for this article is retained by the author(s), with first publication rights granted to the journal.

This is an open-access article distributed under the terms and conditions of the Creative Commons Attribution license which permits unrestricted use, distribution, and reproduction in any medium, provided the original work is properly cited. 